\title{
Market and Brand Positioning and Sustainability Strategies in International Marketing
}

\author{
Selminaz ADIGÜZEL
}

Harran University Siverek Faculty of Applied Sciences International Trade and Logistics Department

\begin{abstract}
Knowing that all failures prepare people for different and more beautiful things rather than being obstacles, and seeing the failure process as an adventure will be the only approach that will bring a person to ultimate success. Marketing has always been an important determinant for companies. There were certain eras which devided marketing techniques to a timeline. During the production period, which was dominating the global system after industrial revolution, marketing methods were simple.

Firms were providing the product which consumer needs, so during that time consumer did not have multiple choices but with the competition involved in the equation and with wider product range, consumer changed his position and became the one who chooses the product. We researched on trademarks, market positioning, brand's innovation, successful innovators, brand management, market segmentation in this article.
\end{abstract}

Keywords: Marketing Methods, Global System, Competition, Consumer.

\section{Introduction}

Liberalization efforts with the development of information technology, almost the world has become a single market. (Görgün, 2020, s. 1) Market Positioning refers to the ability to influence consumer perception regarding a brand or product relative to competitors Integration of country economies with each other and world trade

Liberalization efforts with the development of information technology, almost the world has become a single market. One of the marketing practices that managers should know in order to become a brand in the global market is market positioning.

\section{The Market Positioning}

Integration of country economies with each other and world trade

The objective of market positioning is to establish the image or identity of a brand or product so that consumers perceive it in a certain way.

For example:

- A handbag maker may position itself as a luxury status symbol

- A TV maker may position its TV as the most innovative and cutting-edge

- A fast-food restaurant chain may position itself as the provider of cheap meals (https://corporatefinanceinstitute.com/resources/knowledge/strategy/market-positioning/, 2020)

The concept of positioning has become one of the fundamental components of marketing management (Hooley et al, 1998). Its importance is further supported by the evidence that indicates a positive relationship between firm performance and well-formulated and clearly-defined positioning activities (Kalafatis et al. 2000; Blankson and Kalafatis, 2004). Porter (1980) developed three generic strategies (cost leadership, differentiation and focus) for creating a defensible position and outperforming competitors in a given industry. Three generic strategies represent three broad types of strategic groups and thus the choice of a strategy "can be viewed as the choice of which strategic group to compete in" (Dess and Davis 1984). Porter (1980) characterizes the sources of competitive advantage as low cost or differentiation, thus businesses may 
position themselves by emphasizing either or both. (European Journal of Business and Management ) (Kera, 2015)

A strategic focus on sustainability implies becoming committed to reaching environmentally oriented travel consumers wherever they are found in the world. Future growth in the tourism industry will need to be guided by a global perspective to maintain competitiveness in an increasingly saturated marketplace. A global perspective to understand key determinants of market competitiveness is critical for the tourism industry to sustain its growth and vitality (Hassan, 2000, s. 290) .

\subsection{Steps of the Market Positioning}

Positioning is the act of designing the company's offering and image to occupy a distinct place in the target market's mind (Blankson, 2004). Positioning entails selecting and highlighting appropriate product features and focusing on segmentation and image-building (Aaker and Shansby, 1982). The term position implies a frame of reference, the reference point being the competition. According to Aaker and Shansby (1982) a "clear positioning strategy can insure that the elements of the marketing program are consistent and supportive (Jalkal, March 2014).

\section{For Market Positioning}

1. Determine company uniqueness by comparing to competitors Compare and contrast differences between your company and competitors to identify opportunities. Focus on firms strengths and how they can exploit these opportunities.

2. Identify current market position Identify at the firm existing market position and how the new positioning will be beneficial in setting at the firm apart from competitors.

3. Competitor positioning analysis Identify the conditions of the marketplace and the amount of influence each competitor can have on each other.

4. Develop a positioning strategy For develop a positioning strategy, firms should develop innovation strategy. Through the preceding steps, Firms should achieve an understanding of what their company is, how their company is different from competitors, the conditions of the marketplace, opportunities in the marketplace, and how their company can position itself.

(https://corporatefinanceinstitute.com/resources/knowledge/strategy/market-positioning/, 2020)

Global sourcing strategy requires close coordination of R\&D, manufacturing, and marketing activities on a global basis. Managing geographically separated R\&D, manufacturing, and marketing activities, those companies face difficult coordination problems of integrating their and their suppliers' operations and adapting them to different legal, political, and cultural environments in different countries.

\section{The Concept of Trademark}

According to the definition of the Turkish Language Association, the concept of trademark is defined as a name or symbol that serves to distinguish a good from another good. According to another definition, a brand is the symbol or name that allows a business to distinguish between the identity of the product and other business products (Islamoglu, 1996, p. 265).

If we look at the definition of the American Marketing Association, it is the combination of all these, such as name, symbol, packaging, color, that distinguishes the goods or services of an institution from the products of another institution (Stanton, 1975, p. 214). In the car industry, every brand has an emblem and they are known with these emblems. For example, when a star emblem is seen in a circle, it is known that the car in question is a Mercedes brand.

According to Kotler and Keller, the relevant definition treats marketing as the process of making companies' communication with consumers more profitable and reaching more consumers in the market (P.KotlerK.Keller, 2012, s. 5).

Brand is the proprietary visual, emotional, rational, and cultural image that one associates with a company or a product. When you think Volvo, you might think safety. When you think Nike, you might think of Michael Jordan or "Just Do It." When you think IBM, you might think "Big Blue." The fact that you remember the brand name and have positive associations with that brand makes your product selection easier and enhances the value and satisfaction you get from the product. (Bhasin, 2019). 
- Benefits,

- Qualifications,

- Values,

- As a personality, it reaches consumers in 4 basic terms.

The products in some categories are very similar to each other Since the products dont have a certain physical property, the separation can be done entirely over the personality of the brand. For example, cigarette brands exist entirely with brand personalities. Here, since all the physical features are almost the same, the personality now makes the brand different (Demir, 2019, s. 25) .Each brand or organization should follow various attack and defense strategies according to the situation in the market. Brands / organizations are divided into market leaders, attacker, market follower or niche brand / organization, depending on their situation. Attack strategies are applied to get new customers or against the market leader. Defense strategies are implemented by brands or market leaders who want to maintain their position in the market. It is possible to group the attack strategies under 5 headings;

Wing Attack

Front Attack

Siege

Guerrilla

Bypass

Wing attack is the method in which communication efforts are maintained by targeting the weak points of the competitor or the consumer. Not understanding the speed and attack are the most important factors in this strategy. Front attack refers to marketing communication activities by directly targeting the competitor. This method is rarely preferred as it is costly (https://www.marketing91.com/market/, 2020)

\subsection{Brand Positioning Strategies}

Firms in various sectors such as information technology, telecommunications, and process technology are integrating products and services into customer solutions (Ulaga and Reinartz, 2011; Epp and Price, 2011; Shankaret al., 2009;Tuliet al., 2007). Brand positioning strategies for industrial firms providing customer solutions (Karenen, 2020, s. 253) Firms main aim has become to reach their potential customers instead of providing the information to the mass which would decrease their return of investment and higher their costs. With the technological revolution social and digital media became a part of daily life for almost every person. This gave a huge opportunity to the firms to introduce and communicate about their products directly to their potential target. The brand is of great importance in a globalizing world, considering that it is a means of distinguishing goods and services of a business from the goods and services of other businesses. Beyond being a name in today's competitive conditions, the brand emerges as a business entity that adds an identity, personality to the product, shaped by the perceptions of consumers, and pioneers consumers in product preferences. Brands are a tool that initiates and shapes the relationship between the business and the buyer (Demir, 2019 , s. i). Technology generally arises from a need. It is invented as a result of these needs. In other words, we can say that technology is the components and tools that offer solutions to social problems. Technology, which has a very wide scope, is called to transform a form of information to be presented to human life.

Technology has great benefits to many sectors (Bardakçi, 2019, p.69). 24\% of the world's adults have a smartphone, typically checking it 150 times per day, spending 141 minutes on it. $70 \%$ of people think small companies understand them better than large, 55\% trust businesses to do the right thing, but only $15 \%$ trust business leaders to tell the truth. The majority of the world's business value is now privately owned. Over $40 \%$ of companies in the Fortune 500 in 2000 were not there in 2010, and by 2020 over $50 \%$ will be from emerging markets (Brand innovation, 2020 ). So we have to change our brand's vision 


\section{Innovation}

Between 2010 and 2020, the world's population will grow from 6.9 to 7.7 billion people, mostly in megacities of the fast-developing world. Most significant for marketers will be the rise of a huge "new middle" consumer class, neither rich nor poor, driving global GDP from $\$ 53$ to $\$ 90$ trillion. But this growth is not a linear extrapolation of the old world. It is a fantastic "kaleidoscope" of changing markets, new customers and priorities, new capabilities and aspirations. A tectonic mash up. The turmoil of financial markets, collapsing banks and defaulting nations, was the dying pains of an old world order. Amidst the shake-up there are new winners and losers. In 2014 China's real GDP growth will be $7.1 \%$ compared to $0.9 \%$ in Europe. However some markets, including Ghana and Nigeria, Brazil and Colombia, Indonesia and Vietnam will grow even faster. As Samsung launches its smart watch and Beijing is recognised as the world's leading city for renewable energies (Brand innovation, 2020 ). More than 450 innovation executives (senior executives and R\&D experts) from more than 400 different companies were surveyed in Global Innovation 1000-named research worldwide. Respondents were asked to identify the most innovative companies. They asked them to identify the companies they thought were the most innovative. The results were striking: Seven of the top 10 innovators were not among the top 10 spenders on innovation. Many of those identified by their peers as top innovators actually spent well below their industry averages on $R \& D$, as a percentage of sales. And, most important, the top 10 innovators turned in better financial performances than the top 10 spenders. The most 10 innovative brands are - Apple, Google, 3M, GE, Toyota, Microsoft, P\&G, IBM, Samsung and Intel

(https://www.bcg.com/publications/2020/most-innovative-companies/successful-innovation, 2020)-

\subsection{The Difference For Successful İnnovators}

From Alibaba to ZaoZao, Ashmei to Zidisha, Azuri and Zipcars, a new generation of brands are rising out of the maelstrom of economic and technological change. These are just a few of the companies who are shaking up market structures and customer expectations. They are disruptive and innovative, start-ups and corporates, in every sector and region, reshaping our world.

These brands are more ambitious, with stretching vision and enlightened purpose. They seemarkets as kaleidoscopes of infinite possibilities, assembling and defining them to their advantage. Most of all they have great ideas. They outthink their competition, thinking bigger and different. They are like speedboats, fast and flexible, outthinking and outplaying the supertankers, steady and stable. They don't believe in being slightly cheaper or slightly better. That is a short-term game of diminishing returns. (Brand innovation, 2020)

To begin with, according to research, they all share what they might describe as a basic "table-stakes" set of innovation capabilities:

--At the ideation stage, an ability to gain insight into customer needs and an understanding of the potential relevance of emerging technologies.

At the product development stage, an ability to engage actively with customers to prove the validity of concepts and to assess market potential and risks, and the ability to leverage existing product platforms into new products.

--At the commercialization stage, an ability to work with pilot users to roll out products carefully but quickly, and to coordinate across the entire organization for an effective launch.

But even more important, the best performing companies develop additional capabilities that are very specific to their chosen innovation strategies. Some companies are technology drivers: Their strategy is to develop leading-edge products. They need to be particularly good at understanding emerging technologies and also skilled at managing product lifecycles. These capabilities, however, are less crucial for need seekers, whose strategy is to identify unmet customer needs and innovate to fill them. Need seekers, on the other hand, require world-class consumer-insight skills. The most successful companies, we found, are those that focus on a particular, specifically aligned set of common and distinct capabilities that enable them to better execute their chosen strategies (https://www.forbes.com/2011/04/04/10-top-innovative-companiesapple-google-leadership-managing-how.html\#1951686e6016, tarih yok). 


\section{Facebook}

Just like Google, Facebook is a company that has exploded in growth as well as being synonymous with unique company culture.

Facebook offers, as do many similar companies, lots of food, stock options, open office space, on-site laundry, a focus on teamwork and open communication, a competitive atmosphere that fosters personal growth and learning and great benefits.

\section{Adobe}

Adobe is a company that goes out of its way to give employees challenging projects and then provide the trust and support to help them meet those challenges successfully. While it offers benefits and perks like any modern creative company, Adobe's is a culture that avoids micromanaging in favor of trusting employees to do their best.

\section{Google}

It would almost seem wrong not to mention Google on a list of companies with great culture. Google has been synonymous with culture for years, and sets the tone for many of the perks and benefits startups are now known for. Free meals, employee trips and parties, financial bonuses, open presentations by high-level executives, gyms, a dog-friendly environment and so on. Googlers are known to be driven, talented and among the best of the best.

\section{Square Space}

This successful startup is regularly voted as one of the best places to work in New York City Its company culture is one that is "flat, open and creative." A flat organization is one where there is no (or very few) levels of management in between staff and executives. This approach is more common among startups, and can be tricky to maintain as a company grows larger, generally requiring groups to form (https://www.entrepreneur.com/article/249174, 2020).

A great example of a powerful brand positioning is the one of Australian Yellow Tail Wines objective was to enter the US Market and to be perceived very differently from the vast majority of wine brands, that all sell complicated products with sophisticated and hard-to-understand wine terminology. Yellow Tail focused their positioning strategy on being perceived as"approachable, easy-to-choose, and fun".

This is how they achieved this brand positioning:

- The product: Yellow Tail developed a wine that is soft and sweet in taste and as approachable as beer and ready-to-drink cocktails. It resulted in an easy-drinking wine that did not require years of experience to develop an appreciation for it.

- The name: A fun and adventurous name that represents the tail of a Kangaroo (as a reference to the Australian origins).

- The visual identity: Designing a fun, colorful and unintimidating packaging design without complicated enological terms.

- The communication strategy: Focusing their communication on in-store activities with brand ambassador that helped the product to be perceived as approachable and funny/down-to-earth ads.

- The price: Offering a price of less than $\$ 10$ to fit be perceived as "approachable" and being used at every festive occasion.

\section{Literature review}

Different authors understand brand positioning slightly differently. Literature shows that there is a development in understanding what positioning means for brand management, moving from advertising strategy to core long-term brand strategy determining consumer perception of the brand. The word „positioning” was first used by Ries and Trout in 1969 in an article in Industrial Marketing (Keegan \& Schlegelmilch, 1999, p. 378) describing a strategy for' staking out turf' or filling a slot' in the mind of target customers. Many authors associate the importance of positioning with advertising concept of USP (Unique selling proposition). One of them, Jack Trout, associates positioning to a great extent to successful 
communication, leaving the preceding process of developing the strategy for this communication (and positioning of a brand or idea) aside, as demonstrated by his statement: "The term positioning means, that the company concentrates on one idea or slogan, with which the consumer identifies himself" (Rivkim \& Trout, 1996). A. Ries and L. Ries stress also the importance of consumer: "Advertisers and agencies do not position product. Consumers do. Companies need to determine what position their products already occupy in the consumers mind and relative to other products: only than they can act to reinforce or change that position." (Ries \& Ries, 2002) The important object in positioning is not the producer (marketer, advertiser) of the brand but the consumers. In brand management, two important points of reference: the target group and competition should be taken into consideration. This approach necessitates a concept of brand positioning in the process of man- agement. Brand positioning defines the brand in question by indicating the differentiating elements in the context of the target group's needs and expectations as well as the competition. Therefore, it is a useful strategic tool which may and should be used in the process of managing an administrative unit (Karolina Janiszewska, 2012).

For Brand Terms "sustainable" and "green" are usually used as synonyms in literature. In this sense, green brands attributes are $\square \mathrm{p} .42 \square$ "ecological"-minimizing the negative impact on natural environment, "equitable"-prevent the marketing promotion of unsustainable social practices, and "economic"encouraging long-term economic development through brand There are many studies referring to the link between sustainability and brand equity. For instance, the Tandberg and Ipsos Mor1 survey confirmed the interdependence among corporate environmental responsibility, brand equity and competitive advantage, explaining that more than $50 \%$ (1 billion) of consumers from their global survey claimed they would prefer to buy product from environmentally responsible company, while almost $80 \%$ (700 million) of workers from the same survey stressed importance of working for environmentally ethical company. Similarly, Gidwani examined more than 1000 companies in 54 countries and showed that there is a strong correlation between brand strength and sustainable practice of a company, putting an accent on employees' treatment and environmental policies, as the leading drivers of the correlation. Chen proposed, by observing consumers' purchase of information and electronic products, three novel constructs of brand equity:1) green brand image, 2) green satisfaction, and 3) green trust. (https://www.researchgate.net/publication/314267607_Brand_Strategies_in_the_Era_of_Sustainability [accessed Aug 31]., 2020).

The strategic significance of brand positioning has been presented by Kotler (1994) who places posi- tioning in his STP concept (Segmenting, Targeting, Positioning). Hence, positioning just like segmentation or the choice of the target group becomes the key foundation for defining a strategy for a brand. Also Davis (2000) takes notice of the strategic significance of brand positioning as the basis for further decisions on brand management.

Temporal (2002) treats positioning as one of a brand's key strategic pillars determining the entire management process. Any strategic decisions related to building up and developing a brand refer to the assumptions behind the positioning. The strategic importance of positioning may be viewed in two fundamental dimensions: internal and external. In the external dimension, by reference to the original meaning of the notion, brand positioning sets the frames of the communication strategy. It defines the major communication idea which may be creatively expressed by means of available methods, techniques and means of execution. Researchers (Rallapalli et al., 2000) used a scale developed by Kahle (1986) called "list of values" (LOV) to discuss marketers' norms. Results from canonical correlation analysis generally indicated that marketers' norms could be partly explained by personal values. Hofstede and Steenkamp (1999) developed an integrated methodology called association pattern technique (APT) based on consumer means-end chains to identify segments in international markets. The means-end methodology also utilized LOV to analyze consumers' value. The value variables used in APT are those from the LOV inventory (Kahle, 1986); that is, several researchers think nine "value" items in LOV are suitable as segmentation variables. LOV classified the terminal values of what Americans pursue into eight groups:

Self-respect;

Security; 
Warm relationships with others;

Sense of accomplishment;

Self-fulfillment;

Being well respected;

Sense of belonging; and

Enjoyment in life (Schiffman and Kanuk, 1994).

There has been extensive debate in this literature regarding the role of resources in attaining sustainable advantages since the phrase 'resource-based view' (RBV) was coined by Wernerfelt (1984). Initially, the resource-based perspective emerged to counter the excessive determinism of the Porterian view of competition (Porter 1980) and was accompanied by empirical work which questioned the pre-eminent role of industry and highlighted the importance of organisational factors (Graham Hooley, 2001)) .

\section{Sustainable Strategy}

According to Gabriela Alvarez from Latitude Switzerland, "sustainability is not a one-for-all model. It is about collaborating, learning, creating, implementing, assessing and constantly evolving." Addressing sustainability as a "real marketing topic" demands entering into the substance of and considering a few facts (Milovanov, 2017, s. 79).

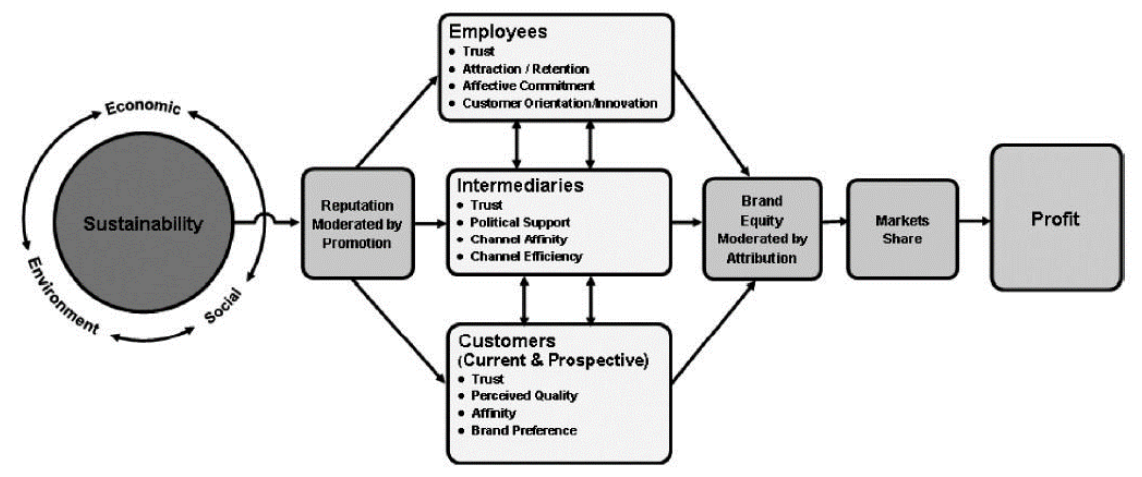

Figure 1: Sustainability-Profitability Relationship Model

\section{Source Nastanski, 2014, p. 169.}

Sustainable strategy demands holistic transformation of business model and synergetic approach; in other words, engagement of multiple stakeholders around a common goal, with the accent on consumer, as the one who makes the final decision whether specific business model will or will not be accepted. Given that marketing discipline has consumers in the center of its philosophy and marketplace as the main playground; and that it has often been accused for creation of uncontrolled consumption of planet resources $\square 3 \square$, marketing managers' responsibility in this sense is the greatest. Accordingly, with the evolution of marketing, especially the green marketing, each aspect of marketing mix has been improved. Green marketing encompasses all marketing activities with the aim to stimulate and sustain environmentallyfriendly attitudes and behavior of consumers (Milovanov, 2017)

5.1. Elements And Structure Of The Positionig Statement In The Place Brand Context 


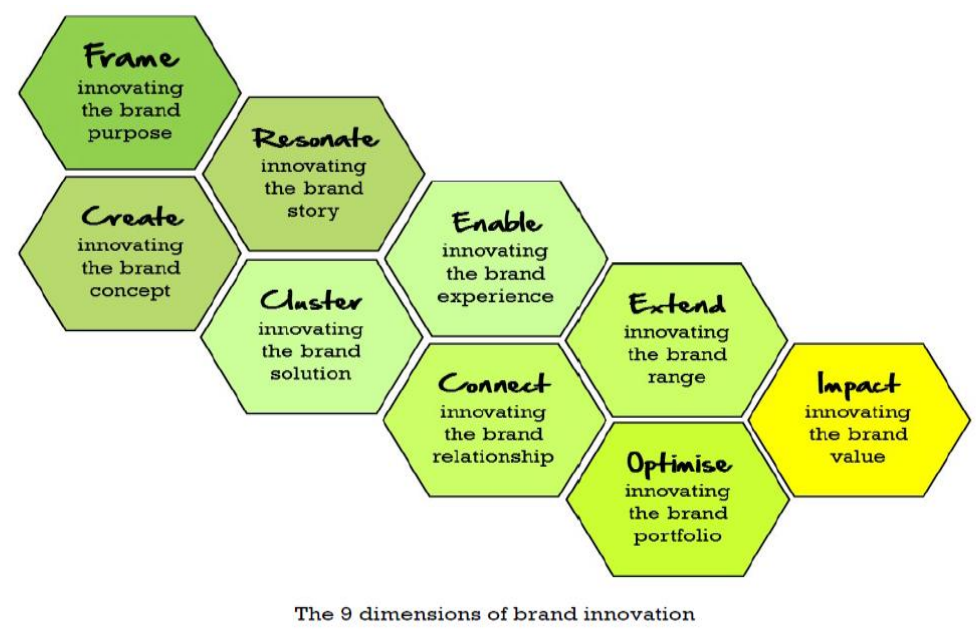

Figure 2: Brand 's 9 dimensioms

Positioning statement is an internal document which synthetically captures brand vision to turn it into the basis of tactical and operational efforts. For the document to be synthetic and brief, it necessitates broad analyses and studies owing to which the positioning statement will contribute to the brand's robustness and value. The key role of the brand positioning statement is to inspire and motivate an organization to pursue activities resulting in growth There are 9 dimensions to brand innovation, ensuring that a powerful idea can create and sustain profitability and growth:

1.Frame, 2 resonate, 3 cluster 4 connect, 5 impact, 6 extend, 7 create, 8 resenate, 9 enable However brand innovation is ultimately an integrated process. Improved clarity of purpose drives everything else. It is also reinforcing, virtuous cycle. A better understanding of the economic value potential of a brand, gives us the mandate to do more.

The brand identity, communication and experience is designed to reflect the target customer. Brands are not about what you do, but what you enable people to do. Brands are about people not productsBrands are about people and passions They articulate what people want to be and achiewe They are emotional and relevelant to their target audences but unlimited in what they can deliver. The relationship between mainstream brands and their consumers have prospered in a way that people want much more for their money - they strive to get the access to all the benefits generated by the company; and, from the standpoint of the companies, that means doing "the right thing" $\square 6 \square$ by contributing to a greater purpose. In words of Paul Polman, CEO of Unilever, "businesses can not succeed in societies that fail. (..) With liberty comes responsibility. Sustainable brands have the heritage, ability and drive to bring this alive." $\square 2$, p. $4 \square$. Sustainability, as a strategy, inevitably emerges in forefront of branding and overall business policy, demonstrating responsible stance toward mankind requirements (Brand Strategies in the Era of Sustainability. Available from: https://www.researchgate.net/publication/314267607_Brand_Strategies_in_the_Era_of_Sustainability [accessed Aug 31, 2020)(Brand innovation, 2020 ) Effective corporate strategies are capabilities driven. Leading companies know what they're good at, how those capabilities create value, and which are the markets where those capabilities can earn them a right to win. Apple as an example. It leads our list of the 10 most innovative. Today Apple epitomizes a capabilities-driven innovation strategy, but it wasn't always so. In the early 1990s the company squandered enormous resources and billions of dollars on a series of failed consumer products like the Newton PDA. Its efforts to do everything itself, building capabilities as varied as cutting-edge hardware development and volume manufacturing, led to huge losses and massive layoffs. But in 1997 Apple began to focus its portfolio and its capabilities. In fact, the company concentrated first on the capabilities at which it excelled, and which differentiated it clearly from peers:- An exceptional consumer experience

--Intuitive user interfaces

--Sleek product design

--Iconic branding 
This focus on what the company did distinctly well helped Apple both narrow and extend its portfolio to products that made the most of these unique capabilities. Rather than expanding more broadly into personal computers (a move that many at the time discussed), the company refocused on its base and specifically targeted consumers and creative professionals with an improved core Mac offering. Rather than seeking world-class performance in manufacturing, Apple sold its factories. Rather than continuing to spend energy and investment on raw technology development, it created a program building on the innovations of others, providing then the true value add of integration, design and branding that has made each product extension a success (https://www.forbes.com/2011/04/04/10-top-innovative-companies-apple-google-leadershipmanaging-how.html\#1951686e6016, 2020).

\section{The Market Model's Challenges for Sustainable Development}

If adopted widely, the market model becomes the foundation for a social experiment of global proportions and with uncertain outcome. Despite very good intentions, the model has serious flaws that require critical examination and decisive, preventive action. One revolves around the question of governance and feasibility of regulation, monitoring and oversight. Since markets barely exist and competition is far from efficient, and because multi-national relationships transcend national sovereignties, there is a need for regulatory mechanisms and bodies. Internal corporate governance issues arise as well, pointing to corporate-level strategy. Another is the question as to how consumption levels of two-thirds of the world's population can be raised to per capita levels of the industrialized countries without raising the global ecological footprint to disastrous impacts on the earth's ecosystems and nature's bio-geo-chemical cycles. While Prahalad and Hart explicitly mention the need for sustainable technologies in serving the poor, it is somewhat puzzling that Prahalad's more recent book (2004a) offers no guidance for the practitioner, nor does it even raise the issue of potential environmental impact. (Kirchgeorg, The Market Model's Challenges for Sustainable Development)

\section{Market segmentation}

Market segmentation is one of the most widely accepted concepts in marketing. Its fundamental thesis is that, to achieve competitive advantage and, thereby, superior financial performance, firms should (1) identify segments of demand, (2) target specific segments, and (3) develop specific marketing "mixes" for each targeted market segment. All marketing strategies involve a search for competitive advantage (Bharadwaj and Varadarajan 1993; Day and Wensley 1988; Varadarajan and Cunningham 1995). Although market segmentation is accepted as a viable strategy for gaining competitive advantage, extant theories of competition in mainstream economics are inhospitable to segmentation strategy. Indeed the dominant theories of competition in mainstream economics, that is, neoclassicalperfect competition and monopolistic competition, view the competitive advantages gained from segmenting markets as detrimental to societal welfare because market segments represent the artificial fragmentation of homogeneous demand, which implies that "segmentation is viewed as an imperfection in the structure of markets"

A number of widely used especially in early applications of market segmentation research are in this category cultural variables geografic variable sgeografic mobility demografic and socio economic variables postal code classifications household life cycle, and firm size standart industrial classific ations and soc1oeconomic variables .

There are four key types of market segmentation that you should be aware of, which include demographic, geographic, psychographic, and behavioral segmentations. It's important to understand what these four segmentations are if you want your company to garner lasting success. Each segment of consumers that you create will have specific wants and needs, which you can effectively accommodate once you've performed the proper research. By making use of market segmentation, your company should benefit from being able to use its resources more efficiently and from making more informed marketing decisions.

. The main benefit of market segmentation is that it can help you create better marketing messages.

The brand identity, communication and experience is designed to reflect the target customer. Look at the typography of Build a Bear Workshop logo, the layout of its stores, the programme of activities - all designed to be child-like. Consider the design of Apple-from its logo to its typography, the black t-shirts of 
its people, and industrial design-they all capture modernity, coolness and simplicity (Brand innovation, 2020 ).

Using market segmentation will also allow you to determine which marketing approaches work best. If your target audience for a specific product is comprised of individuals who are between the ages of 25-29, it's likely that a campaign that uses digital marketing at a higher rate than traditional marketing will see better results. Market segmentation gives you the ability to create highly targeted ads that are centered around one or two traits, which should make your marketing campaigns more effective (4 Key Types of Market Segmentation: Everything You Need to KnowKnow Unıversity Lab Partners, 2020).

The geographic market segmentation effectively split your entire audience based on where they are located, which is useful when the location of the customers plays a part in their overall purchase decisions https//studycom/academy/lesson/what-is-geographic-segmentation-in-marketing definition-advantagesexamples. (What Is Geographic Segmentation in Marketing? - Definition, Advantages \& Examples, 2020).

Kotler (1997) has proposed that consumer markets should be divided according to geographic, demographic, psychographic, and behavioral variables.

In psychographic segmentation, consumers are divided into different groups on the basis of lifestyle and personality (Kotler, 1997). Customers within the same demographic group can exhibit very different psychographic profiles. Therefore, enterprises making different consumer goods can seek marketing opportunities in lifestyle/personality segmentation (Kim, 1993; Lee and Ferber, 1977). (https://www.emerald.com/insight/content, 2002) (Segmenting customer brand preference: demographic or psychographic, 2002) (Lin, 2002, s. 1)

\section{Table 1: Market Segmentation Strategy}

\begin{tabular}{|c|c|c|c|c|c|}
\hline Market & Product & Product & Price & Promotion & Place \\
\hline Segment & Line & Strategy & Strategy & Strategy & Strategy* \\
\hline $\begin{array}{l}\text { Homeowners/ } \\
\text { Do-it-yourselfers }\end{array}$ & Black \& Decker & $\begin{array}{l}\text { Quality adequate } \\
\text { for occasional use }\end{array}$ & Lower price & $\begin{array}{l}\text { TV ads during } \\
\text { holidays }\end{array}$ & $\begin{array}{l}\text { Kmart, } \\
\text { Bunnings } \\
\text { Warehouse, } \\
\text { Mitre } 10 \\
\text { (lower tier } \\
\text { stores), etc. }\end{array}$ \\
\hline Weekend Warriors & Firestorm & $\begin{array}{l}\text { Quality adequate } \\
\text { for regular use }\end{array}$ & $\begin{array}{l}\text { Higher priced } \\
\text { than B\&D brand }\end{array}$ & $\begin{array}{l}\text { Ads in } \\
\text { DIY magazines/ } \\
\text { shows }\end{array}$ & $\begin{array}{l}\text { Bunnings, } \\
\text { Warehouse, } \\
\text { etc. }\end{array}$ \\
\hline Professional Users & DeWalt & $\begin{array}{l}\text { Quality adequate } \\
\text { for daily use }\end{array}$ & Highest price & $\begin{array}{l}\text { Sales reps } \\
\text { call on job sites }\end{array}$ & $\begin{array}{l}\text { Bunnings } \\
\text { Warehouse, } \\
\text { Mitre } 10 \\
\text { (top tier } \\
\text { stores),etc. }\end{array}$ \\
\hline
\end{tabular}

Source: Based on Black \& Decker (2001).

For example, how Black \& Decker (hereafter,B\&D) used a global market segmentation strategy to reverse the performance of its power tools division in the 1990s. As Table 1 shows, B\&D segments users of power tools into three groups. The first segment consists of homeowners/do-it-yourselfers and is characterized by people who: (1) use power tools occasionally, (2) are price sensitive, and (3) tend to buy power tools at low price retailers (e.g., Kmart). The second segment, "weekend warriors," contains people who: (1) use power tools on a regular basis, (2) are less price sensitive, and (3) tend to buy tools at home centers (e.g., Bunnings Warehouse). The third segment, professional users,consists of people who: (1) use power tools on a dailybasis, (2) are willing to pay more for their power tools, and (3) tend to buy power tools from vendors that cater to professional contractors (e.g., Bunnings Warehouse, Aussie Weld, and Spinefex). To target each segment, B\&D uses specific products lines with different brand name.s In a multi-dimensional market, 
companies can increase profitability by utilizing market segmentation. An effective market segmentation technique depends on selecting the relevant segmenting bases and descriptors (Wind, 1978). Segmentation variables must be considered in light of their measurability, availability, reliability and ability to uncover the characteristics of each market segment. Researchers (Becker et al., 1985; Becker and Conner,1981) have tried to divide consumer markets by looking at a consumer's "personality".Jain (1993) analyzed markets through social, economic, and special segmentation variables such as brand loyalty and consumer attitude.

The psychographic market segmentation is aimed at separating the audience based on their personalities. The different traits within this segmentation include lifestyle, attitudes, interests, and values. The behavioral market segmentation divides your whole audience based on the previous behavior that they've exhibited with your brand. Some of the main traits within this segmentation type include product knowledge, purchase patterns, previous purchases, awareness of your business, and product rating.

The psychographic market segmentation is aimed at separating the audience based on their personalities. The different traits within this segmentation include lifestyle, attitudes, interests, and values.

. First of all, you'll want to analyze your current customers via market research. This research can be performed in a many different ways, which include by interviewing customers, interviewing members of your sales team, using the website analytics that you've gathered, researching audience interests, and identifying what your customers are searching for on search engines.

Once you've gathered all of this data, you should create a detailed buyer personal for your core audience, which gives you the ability to better visualize the customer you want to appeal to with your products and marketing efforts. With the buyer persona in hand, you can start to look for market segment opportunities. Try to match elements of your brand and what you can offer with opportunities from the buyer persona.

Consider looking for segments that aren't currently being served. Once you've found several possible segments, you can research it to see what the competition provides and if your audience would be responsive to what you offer. If you're building a marketing campaign around this data, you should think about creating several campaigns to test your ideas. If one campaign provides to be more effective than the others, this could be an effective strategy going forward (https://www.universitylabpartners.org/blog/key-types-marketsegmentation-everything-you-need-to-know, tarih yok). All market segmentation strategies are premised on three basic assumptions. (1) Many markets are significantly, but not completely, heterogeneous regarding consumers' needs, wants, use requirements, tastes, and preferences, and, therefore, can be divided into smaller, meaningful, relatively homogeneous segments of consumers (2) A firm's market offerings (here, including price, promotion, and channels) can often be designed to meet the needs, wants, tastes, and preferences of such segments. And (3), for many firms, a strategy of targeting specific segments can lead to competitive advantages in the marketplace and, in turn, superior financial performance (Arnett, 2004, s. 78). The continued success of today's major companies depends on their ability to gain and maintain at least one source of competitive advantage over their actual and potential rivals (Porter 1980). More recent advice to managers responsible for strategic decisions is to return to basics and focus on the search for sustainable competitive advantage (Day and Wensley, 1988; and Cravens, 1988). In today's intensively competitive markets a successful company must constantly reassess its sources of competitive advantage, ensure that the company's key success factors are regularly reviewed, effectively communicated throughout the organisation and reinforced and monitored through the performance measurement system. Moreover, to preserve their competitive position in the face of increased intensity of global competition, companies need to constantly monitor the market place and consequently managers should be increasingly interested in information about the present performance and future strategy of not only those already operating in the same market but also those with the potential to enter any of the company's markets (Whittington, 1997, s. 217). Two starting points have been suggested for the development of marketing strategies. The bulk of the marketing literature advocates an external orientation to strategy development through focusing on the market environment, and in particular customer requirements and competitor actions. The second departure point is firm or organisational resources. Under this approach strategy begins at home, with a clear identification of the differentiating resources (assets and capabilities) at the firm's disposal. Once these resources have been identified a match is sought with the potential customers, and strategies and actions developed to leverage the resources in identified markets. More recently researchers have begun to advocate bringing together 
these two perspectives into what has been termed asset (or resource) based marketing (Hooley and Saunders 1993), market-led capabilities (Day 1994) and resource-advantage theory (Hunt and Morgan 1996) where the importance of both an external and an internal view have been recognised.

The relation between consumer brand preference and the characteristics of a sub-market is the key for marketers to develop effective sub-marketing strategies. Utilizing different market segmentation variables can provide more valid information to understanding the brand preference of each segment. Most companies don't have enough resources to target a mass market. Which is why they need to target the specific market segment that need their product. They divide the market into similar and identifiable segments through market segmentation. Demographic segmentation is the easiest way to divide a market. Mixing demographic segmentation with another type of market segmentation can help to narrow your market down even further. Many successful businesses continue to grow simply because they really understand their markets and their customers. One of the most popular techniques businesses can use to better target their products at the right customers is market segmentation. Competitive digital marketing strategies necessitates analysing the next step a consumer may take. This kind of analysis can only be achieved through predictive market segmentation. Technological innovation continues to evolve the customers needs and preferences. Businesses are modernizing the way they target digital consumers, in order to maximize value in each segment

\subsection{Competitive Marketing}

In the strategic management literature key individual firm resources are assessed for their ability to create a sustainable competitive advantage based on the extent to which they exhibit isolating properties 


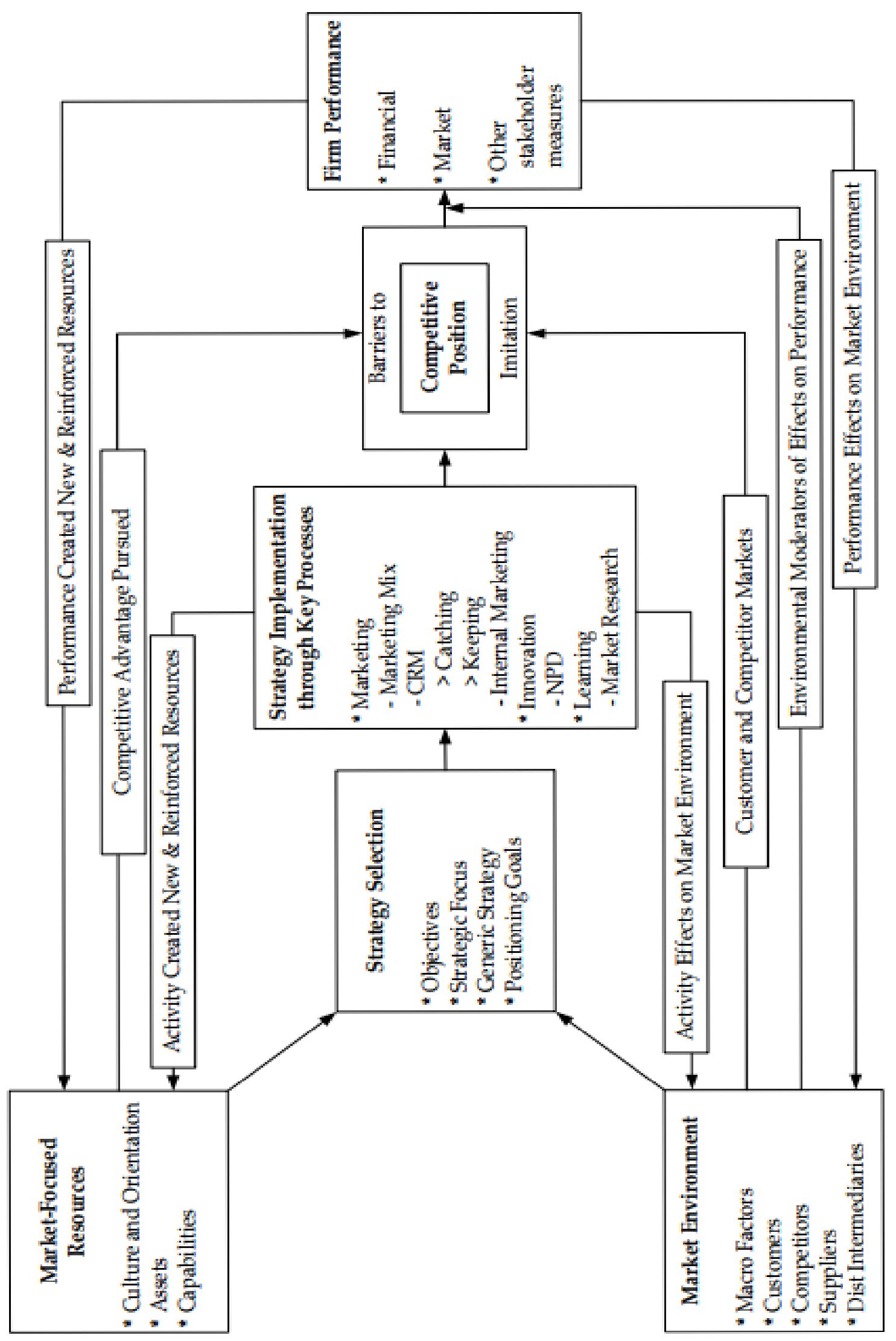

Figure 1: Market-Focused Resources, Competitive Positioning and Firm PerformanceSource: (Graham Hooley, 2001). 
From the marketing perspective we could propose that the creation of a competitive position is the outcome of deploying those individual resources towards satisfying targeted customers. Thus the competitive position achieved can itself be tested for sustainability by assessing the extent to which it exhibits isolating mechanism properties such as those listed above. Two starting points have been suggested for the development of marketing strategies. The bulk of the marketing literature advocates an external orientation to strategy development through focusing on the market environment, and in particular customer requirements and competitor actions. The second departure point is firm or organisational resources. Under this approach strategy begins at home, with a clear identification of the differentiating resources (assets and capabilities) at the firm's disposal.

Intuitively this is reasonable, as the impact of a firm's own orientation, and subsequent actions in the market place, is likely to be effected by the actions of competitors, together with general market conditions. Under the proposed model environmental factors are proposed as moderators of the effects of competitive position achieved on firm performance (Graham Hooley, 2001, s. p 506)

\section{Result}

The important object in positioning is not the producer (marketer, advertiser) of the brand but the consumers. In brand management, two important points of reference: the target group and competition should be taken into consideration. In today's intensively competitive markets a successful company must constantly reassess its sources of competitive advantage, ensure that the company's key success factors are regularly reviewed, effectively communicated throughout the organisation and reinforced and monitored through the performance measurement system. Recently researchers have begun to advocate bringing together these two perspectives into what has been termed asset (or resource) based marketing, market-led capabilities and resource-advantage theory In this article, we talked about the marketing strategies of companies, what they should do in creating a marketing brand, The Market Model's Challenges for Sustainable Development. We have included sustainable marketing, marketing strategies and literature studies. Particularly important in setting strategic direction will be the vision and mision of global proportions Using market segmentation will also allow you to determine which marketing approaches work best. In a multi - dimensional market, companies can increase profitability by utilizing market segmentation. An effective market segmentation technique depends on selecting the relevant segmenting bases and descriptors Segmentation variables must be considered in light of their measurability, availability, reliability and ability to uncover the characteristics of each market segmentyour current customers via market research. Marketing Research can be performed in a many different ways, which include by interviewing customers, interviewing members of your sales team, using the website analytics that you've gathered, researching audience interests, and identifying what your customers are searching for on search engines. Ithe impact of a firm's own orientation, and subsequent actions in the market place, is likely to be effected by the actions of competitors, together with general market conditions.

A marketing strategy refers to a business's overall plan for reaching prospective consumers and turning them into customers of the products or services the business provides.

A marketing strategy contains the company's value proposition, culture, key brand messaging, data on target customer, demographics, and other element of firms Strong firms need leaders with strong strategies. Every strong firm draws its strength from strong leaders who believe in marketing strategies.

\section{References}

[1.] Arnett, 2004,. Market Segmentation Strategy, Competitive Advantage, and Public Policy: Grounding Segmentation Strategy in Resource-Advantage Theory Shelby Australasian Marketing Journal (AMJ) Volume 12, Issue 1, 2004, P 7-25

[2.] Bardakçi H, 2019, İnovasyon ve Öz yeteneğe dair her şey. Cinius yayınları. Ekim. İstanbul,

[3.] Bhasin, H, 2019,. Tagged Branding. https://www.marketing91.com/what-is-a-brand/.

[4.] Fisk P Brand innovation. 2015. http://www.thegeniusworks.com/wpcontent/uploads/2015/10/Brand-Innovation-Article. adresinden alındı 
[5.] Brand Strategies in the Era of Sustainability. Available from: https://www.researchgate.net/publication/314267607_Brand_Strategies_in_the_Era_of_Sustainabil ity [accessed Aug 31., 2020..

[6.] Demir, U. S, 2019. Markalaşma ve Hedef Pazar Belirleme Lüksemburg Ülke Markalaşması Üzerine Vaka Çalışması Yüksek Lisans Tezi Sosyal Bilimler Enstitüsü M.A. Uluslararası Ticaret ve Lojistik Tez European Journal of Business and Management . (31.08.2020).

[7.] Jalkal, J. K. (March, 2014,. Three Strategies For Customervalue Assessment İn Businessmarket. Management Decision 52(1).

[8.] Görgün, M. R.,2020, Uluslararası Lojistik Karayolu ve Navlun Hesaplamaları. Nobel Yayınevi.

[9.] Hassan, S. S , 2000,. Determinants of Market Competitiveness in an Environmentally Sustainable Tourism Industry. Journal of Travel Research, 290.

[10.] Karenen, J. \&., 202008 31. Brand Positioning Strategies For İndustrial Firmsproviding Customer Solutions.H.. 2020., Dü. Aculty Of Technology Management, Department Of Industrial Management, Lappeenranta University Of Technology,Lappeenranta, Finland,

[11.] Karolina J. 2012 "The Strategic İmportance Of Brand Positioning İn The Place Brand Concept: Elements, Structure And Application Capabilities”, Journal Of International Studies,. S. , Pp. 9-19.

[12.] Kera, J. 2015. İnnovation Types And Firm Performance Linkage , Effect Of Market Positioning On Market Orientation. European Journal Of Business And Management, Vol.7, No.23,

[13.] Lin, C.-F. 2002, Segmenting Customer Brand Preference: Demographic Or Psychographic. Journal Of Product \& Brand Management, 11(4).

[14.] Michel Wedel, W. A, 2020. Market Segmentation: Conceptual And Methodological Foundations .

[15.] Milovanov A. G. ,2017,. Brand Strategies In The Era Of Susta1nability Brand Strategies İn The Era Of Sustainability. Available From:

Https://Www.Researchgate.Net/Publication/314267607_Brand_Strategies_İn_The_Era_Of_Sustai nability [Accessed Aug 31 2020].

[16.] P.Kotler-K.Keller. 2012. Marketing Management. England. Marketing Management: European Edition.

[17.] Segmenting Customer Brand Preference: Demographic or Psychographic. (2002). 2. Segmenting Customer Brand Preference: Demographic Or Psychographic. Adresinden Alınd

[18.] What Is Geographic Segmentation in Marketing? - Definition, Advantages \& Examples. (2020). https://study.com/academy/lesson/what-is-geographic-segmentation-in-marketing-definitionadvantages-examples.html. adresinden alındı.

[19.] Whittington, K. B,. 1997, 13 Intense Competition, Revised Strategies and Financial Performance in the U.K. Food Retailing Sector .

[20.] https://www.forbes.com/2011/04/04/10-top-innovative-companies-apple-google-leadershipmanaging-how.html\#1951686e6016. adresinden alind1 (2002). https://www.emerald.com/insight/content. adresinden alınd1

[21.] https://corporatefinanceinstitute.com/resources/knowledge/strategy/market-positioning/. adresinden alınd1 4 Key Types of Market Segmentation: Everything You Need to KnowKnow University Lab Partners. (2020)

[22.] . https://www.universitylabpartners.org/blog/key-types-market-segmentation-everything-you-needto-know adresinden alındı

[23.] https://corporatefinanceinstitute.com/resources/knowledge/strategy/market-positioning/. (2020).

[24.] https://www.bcg.com/publications/2020/most-innovative-companies/successful-innovation. (2020).

[25.] https://www.entrepreneur.com/article/249174. (2020, 08).

[26.] https://www.forbes.com/2011/04/04/10-top-innovative-companies-apple-google-leadershipmanaging-how.html\#1951686e6016. (2020).

[27.] https://www.marketing91.com/market/. (2020). https://www.marketing91.com/market/.

[28.] https://www.researchgate.net/publication/314267607_Brand_Strategies_in_the_Era_of_Sustainabil ity [accessed Aug 31]. (2020, 08). 
[29.] https://www.universitylabpartners.org/blog/key-types-market-segmentation-everything-you-needto-know. (tarih yok). ULP EUniversitympowers the Next Generation of Innovators. adresinden alındı 